\title{
Physicochemical characterization of a novel graphene-based magnetic resonance imaging contrast agent
}

This article was published in the following Dove Press journal:

International Journal of Nanomedicine

2 August 2013

Number of times this article has been viewed

\author{
Shruti Kanakia' \\ Jimmy D Toussaint' \\ Sayan Mullick Chowdhury' \\ Gaurav Lalwani' \\ Tanuf Tembulkar' \\ Terry Button ${ }^{1,2}$ \\ Kenneth R Shroyer ${ }^{3}$ \\ William Moore ${ }^{2}$ \\ Balaji Sitharaman' \\ 'Department of Biomedical \\ Engineering, ${ }^{2}$ Department of \\ Radiology, ${ }^{3}$ Department \\ of Pathology, Stony Brook \\ University, Stony Brook, NY, USA
}

Correspondence: Balaji Sitharaman Department of Biomedical Engineering, Bioengineering Building, Rm \#II5, Stony Brook University, Stony Brook, NY I I794-528I, USA

$\mathrm{Tel}+\mid$ 63| 632 I8I0

Email balaji.sithararaman@stonybrook.edu

\begin{abstract}
We report the synthesis and characterization of a novel carbon nanostructure-based magnetic resonance imaging contrast agent (MRI CA); graphene nanoplatelets intercalated with manganese $\left(\mathrm{Mn}^{2+}\right)$ ions, functionalized with dextran (GNP-Dex); and the in vitro assessment of its essential preclinical physicochemical properties: osmolality, viscosity, partition coefficient, protein binding, thermostability, histamine release, and relaxivity. The results indicate that, at concentrations between 0.1 and $100.0 \mathrm{mg} / \mathrm{mL}$, the GNP-Dex formulations are hydrophilic, highly soluble, and stable in deionized water, as well as iso-osmolar (upon addition of mannitol) and isoviscous to blood. At potential steady-state equilibrium concentrations in blood $(0.1-10.0 \mathrm{mg} / \mathrm{mL})$, the thermostability, protein-binding, and histamine-release studies indicate that the GNP-Dex formulations are thermally stable (with no $\mathrm{Mn}^{2+}$ ion dissociation), do not allow non-specific protein adsorption, and elicit negligible allergic response. The $r_{1}$ relaxivity of GNP-Dex was $92 \mathrm{mM}^{-1} \mathrm{~s}^{-1}$ (per- $\mathrm{Mn}^{2+}$ ion, $22 \mathrm{MHz}$ proton Larmor frequency); 20- to 30-fold greater than that of clinical gadolinium $\left(\mathrm{Gd}^{3+}\right)$ - and $\mathrm{Mn}^{2+}$-based MRI CAs. The results open avenues for preclinical in vivo safety and efficacy studies with GNP-Dex toward its development as a clinical MRI CA.
\end{abstract}

Keywords: manganese, dextran, preclinical, physicochemical properties, relaxivity, graphene, magnetic resonance imaging, contrast agent

\section{Introduction}

Magnetic resonance imaging (MRI) is a central whole-body imaging technique used to visualize anatomical structures in biomedical research and clinical medicine. The application of MRI contrast agents (CAs) has enabled improvements in diagnostic confidence as a result of better contrast achieved by shortening the characteristic $T_{1}$ or $T_{2}$ relaxation time of in vivo water protons. Since the $1980 \mathrm{~s}$, researchers have developed a variety of clinical MRI CAs that are complexes of paramagnetic metal ions such as gadolinium $\left(\mathrm{Gd}^{3+}\right)$, manganese $\left(\mathrm{Mn}^{2+}\right)$, or iron $\left(\mathrm{Fe}^{2+}\right) \cdot{ }^{1,2} \mathrm{The} \mathrm{Gd}^{3+}$ chelate-based $T_{1} \mathrm{MRI}$ CAs currently dominate the market ( $>95 \%$ market share) and, in the USA, approximately $45 \%$ of the 28 million clinical MRI procedures use MRI CAs. ${ }^{3}$ Recently, the US Food and Drug Administration (FDA) restricted the clinical use of $\mathrm{Gd}^{3+}$ chelatebased $T_{1}$ MRI CAs for patients affected by renal failure. ${ }^{4,5}$ Thus, there is a need for a $T_{1}$ MRI CA that is safer and more efficacious than clinical $\mathrm{Gd}^{3+}$ chelate-based agents, and agents employing $\mathrm{Mn}^{2+}$ ions have been proposed as possible alternatives. ${ }^{2}$

The two-dimensional carbon nanostructure graphene has attracted a great deal of attention for biomedical applications owing to its unique physicochemical properties. ${ }^{6}$ Recently, we thoroughly and systematically investigated the structural, chemical, magnetic, and relaxometric properties of a novel $\mathrm{Mn}^{2+}$ intercalated graphene nanostructure known as "graphene oxide nanoplatelets."” Our results indicate that these nanoparticles 
are disc-shaped with diameters $\sim 20-40 \mathrm{~nm}$ and thickness $\sim 2-3 \mathrm{~nm}$, paramagnetic, and their suspensions (0.1-1.0 mg/ $\mathrm{mL}$ concentrations) in biocompatible Pluronic ${ }^{\circledR}$ F-127 (1 wt\%; \# P-3000MP, Life Technologies, Carlsbad, CA, USA) solutions at clinically relevant magnetic fields (eg, 1.5 Tesla) show an order of magnitude or greater $r_{1}$ relaxivity ${ }^{7}$ (relaxivity $r_{1}$ or $r_{2}$ is a measure of the efficacy of an MRI CA, and is defined as the change in relaxation rate [inverse of $T_{1}$ or $T_{2}$ relaxation time] per unit concentration of the MRI CA ${ }^{1}$ ) than clinical $\mathrm{Gd}^{3+}$-based (eg, Magnevist ${ }^{\mathrm{TM}}$, Bayer Schering Pharma, Berlin-Wedding, Germany) or $\mathrm{Mn}^{2+}$ chelate-based (eg, Teslascan [GE Healthcare, Little Chalfont, UK]) MRI CAs. ${ }^{8}$ The high relaxivity may allow the development of MRI CAs that show the same clinical MRI performance at substantially lower dosages, and could also allow their development for advanced applications such as MRI CAs for extended-residence-intravascular, tissue (organ)-specific, and molecular imaging. However, to translate this promising MRI CA into the clinic, the hydrophobic graphene nanoplatelets need to be water solubilized at much higher concentrations (in the range of tens of $\mathrm{mg} / \mathrm{mL}$ ) with suitable biocompatible moieties, and their stability needs to be ensured at these high concentrations in biological media or blood. Additionally, in vitro and in vivo preclinical assessment of the water-soluble graphene oxide nanoplatelet formulation's physicochemical characteristics, toxicity, and efficacy is necessary according to the US FDA guidelines. ${ }^{9-11}$

As a first step in their preclinical development, we have synthesized and characterized highly water-soluble $\mathrm{Mn}^{2+}$ intercalated graphene nanoplatelets non-covalently functionalized with the natural polymer dextran (hereafter called GNP-Dex), and have assessed eight key in vitro physicochemical properties (osmolality, viscosity, partition coefficient, protein binding, thermostability, histamine release, relaxivity, and in vitro phantom MRI) required by the US FDA during an investigational new drug application of MRI CAs for approval to perform first-in-human trials. ${ }^{9-11}$

\section{Methods}

\section{Synthesis of GNP-Dex}

The $\mathrm{Mn}^{2+}$ intercalated graphene oxide nanoplatelets (GNPs) were prepared according to the previously described method. ${ }^{7}$ The GNPs were non-covalently functionalized with dextran (technical grade, MW 10,000 Da; Pharmacosmos, Hobaek, Denmark) to synthesize GNP-Dex as follows. GNPs and dextran were mixed in distilled deionized (DDI) water at a 1:10 weight ratio, and bath sonicated for 30 minutes followed by the addition of ammonium hydroxide $\left(\mathrm{NH}_{4} \mathrm{OH}\right)$. The mixture was then stirred at $95^{\circ} \mathrm{C}$ for 3 hours. Next, the particles were centrifuged at 1,000 rpm for 15 minutes, and the supernatant was carefully transferred into Falcon ${ }^{\mathrm{TM}}$ tubes (BD Biosciences, San Jose, CA, USA) to obtain water-soluble GNP-Dex. The supernatant was lyophilized and the solid powder resuspended in DDI water at desired concentrations. The $\mathrm{Mn}^{2+}$ ion concentration in GNP-Dex was measured by inductively coupled plasma mass spectrometry (ICP-MS) and $\mathrm{Mn}^{2+}$ weight percent in the GNP-Dex was measured to be $0.064 \%$. Mannitol (M8129, Sigma-Aldrich, St Louis, MO, USA) was added to the GNP-Dex solutions to regulate the osmolality within the range of blood (290-320 mOsm/kg).

\section{Characterization of the GNP-Dex}

\section{Transmission electron microscopy}

Transmission electron microscopy (TEM) was performed using a JEOL JEM-2100F high-resolution Transmission Electron Microscope (Tokyo, Japan) at the Center for Functional Nanomaterials, Brookhaven National Laboratory, Upton, New York, USA. The GNP-Dex solutions $(1 \mathrm{mg} / \mathrm{mL})$ were sonicated for 1 minute then centrifuged at 5,000 rpm for 5 minutes. A drop $(10 \mu \mathrm{L})$ of the resulting supernatant was placed on TEM grids (300 mesh size, holey lacey carbon, Ted Pella, Inc, Redding, CA, USA), dried, and imaged at $200 \mathrm{kV}$ accelerating voltage.

\section{Atomic force microscopy}

After sonication and centrifugation (5,000 rpm, 5 minutes), the GNP-Dex solutions were spin coated at 3,000 rpm for 5 minutes on freshly cleaved silicon wafers (Ted Pella, Inc.). A V-shaped cantilever of frequency $f_{c}=145-230 \mathrm{kHz}$, $\mathrm{L}=225 \mu \mathrm{m}, \mathrm{W}=40 \mu \mathrm{m}$, tip radius $<10 \mathrm{~nm}$, and spring constant k = 20-95 N/m (ACL-10, Applied NanoStructures, Inc., Mountain View, CA, USA) were used. Samples were imaged using a NanoSurf ${ }^{\circledR}$ EasyScan 2 FlexAFM (NanoScience Instruments, Inc., Phoenix, AZ, USA) operating in tapping mode under ambient conditions $\left(50 \%\right.$ relative humidity, $\left.25^{\circ} \mathrm{C}\right)$.

\section{Thermogravimetric analysis}

Thermogravimetric analysis (TGA) was performed on GNPs, dextran (MW 10,000 Da), and GNP-Dex using a PerkinElmer Diamond 500 (Waltham, MA, USA) instrument at Brookhaven National Laboratory. The samples were heated from $50^{\circ} \mathrm{C}$ to $700^{\circ} \mathrm{C}$ at a heating rate of $10^{\circ} \mathrm{C} / \mathrm{min}$ under an airflow of $100 \mathrm{~mL} / \mathrm{min}$.

\section{Elemental analysis}

The GNP-Dex samples were analyzed by ICP-MS (Finnigan $^{\mathrm{TM}}$ ELEMENT 2, Thermo Fisher Scientific, 
Waltham, MA, USA) to determine the concentration of $\mathrm{Mn}^{2+}$ ions. For the ICP analysis, liquid GNP-Dex samples (of known concentration) were treated with concentrated nitric acid $\left(\mathrm{HNO}_{3}\right)$ and carefully heated to obtain a solid residue. Next, this residue was treated with $30 \% \mathrm{H}_{2} \mathrm{O}_{2}$ and heated again to remove any carbonaceous material. The remaining non-carbonaceous solid residue was dissolved in $2 \% \mathrm{HNO}_{3}$ and analyzed by ICP-MS.

\section{Physicochemical properties assessment Osmolality}

The osmolality of $300 \mu \mathrm{L}$ GNP-Dex solutions at concentrations $100.0,50.0,20.0,10.0$, and $0.4 \mathrm{mg} / \mathrm{mL}$ were measured using a freezing point depression osmometer (model no 3D3, Advanced Instruments, Norwood, MA, USA). Mannitol, an osmotic diuretic agent, was added to adjust their osmolality to obtain values similar to that of blood.

\section{Viscosity}

The viscosity of the GNP-Dex formulations at concentrations $100.0,50.0,20.0,10.0$, and $0.4 \mathrm{mg} / \mathrm{mL}$ with sample volume of $700 \mu \mathrm{L}$ were measured using a rotating spindle viscometer (DV-I Prime Digital Viscometer, Brookfield Engineering, Middleboro, MA, USA) at $37^{\circ} \mathrm{C}$.

\section{Partition coefficient}

The partition coefficient was measured using the well-established flask-shaking method. ${ }^{12}$ Briefly, $100 \mu \mathrm{L}$ of $20 \mathrm{mg} / \mathrm{mL}$ GNP-Dex solution was added to a Falcon tube that contained 1-octanol/DDI water mixture $(1 \mathrm{~mL}$ each phase, $\mathrm{n}=3$ ). The two phases were thoroughly mixed by vigorously shaking the Falcon tube for $\sim 30$ seconds. The Falcon tube was then kept still for 120 minutes at room temperature to allow the two phases to separate. Aliquots of the aqueous phase were removed after 145, 205, and 255 minutes. The concentration of the nanoparticles in aqueous phase was determined by ultraviolet-visible (UV-Vis) spectrophotometry using an Evolution 300 UV-Vis Spectrophotometer (Thermo Fisher Scientific) at $254 \mathrm{~nm}$ wavelength. The partition coefficient $\left(\mathrm{P}_{\text {ow }}\right)$ was calculated as logarithm of the ratio of the GNP-Dex concentrations in octanol to water phase as follows: $\log \mathrm{P}_{\text {ow }}=\log$ ([nanoparticles] octanol/[nanoparticles] DDI water).

\section{Protein binding}

Protein binding was studied using an MB 74-1610 MicroEquilibrium Dialyzer ${ }^{\mathrm{TM}}$ (Harvard Apparatus, Holliston, MA, USA). The protein human serum albumin (HSA) and GNP-Dex $(500 \mu \mathrm{L}$ each) at concentrations of $0.1,1.0$, and $10.0 \mathrm{mg} / \mathrm{mL}(\mathrm{n}=3$ per concentration) were pipetted into two separate chambers of the dialyzer. The two chambers were partitioned with a cellulose acetate membrane $(100 \mathrm{kDa}$, molecular weight cut off). The dialysis chamber was allowed to equilibrate at $37^{\circ} \mathrm{C}$ in an incubator for 24 hours. The samples from each chamber were pipetted out at the end of 24 hours. The equilibrated concentration of HSA in both the compartments was quantified by colorimetry using bicinchoninic acid (BCA) assay (BCA Pierce ${ }^{\circledR}$ BCA Protein Assay Kit, Thermo Fisher Scientific) at $562 \mathrm{~nm}$, using a plate reader (Infinite ${ }^{\circledR}$ M200, Tecan Group Ltd, Morrisville, NC, USA).

\section{Thermostability}

The thermal stability of the intercalated $\mathrm{Mn}^{2+}$ ions in the GNP-Dex formulations was characterized at physiological temperature $\left(37^{\circ} \mathrm{C}\right)$, and compared with the concentration of free $\mathrm{Mn}^{2+}$ ions in the formulation at room temperature $\left(25^{\circ} \mathrm{C}\right)$. One milliliter of each of the 20,50 , and $100 \mathrm{mg} / \mathrm{mL}$ concentration GNP-Dex solutions was incubated at $25^{\circ} \mathrm{C}$ and $37^{\circ} \mathrm{C}$ for 24 hours, followed by centrifugation at 7,000 rpm for 10 minutes. The supernatants were analyzed for the presence of free $\mathrm{Mn}^{2+}$ ions using sodium bismuthate $\left(\mathrm{NaBiO}_{3}\right)$ assay. ${ }^{7}$ A standard optical absorbance versus concentration curve was prepared with known concentrations of potassium permanganate $\left(\mathrm{KMnO}_{4}\right)$, which has distinctive pink color, using UV-Vis spectrophotometry at $578 \mathrm{~nm}$. This standard curve was used to obtain the unknown concentration of permanganate $\left(\mathrm{MnO}^{4-}\right)$ ions produced by the $\mathrm{NaBiO}_{3}$ reaction by measuring the absorbance values at $578 \mathrm{~nm}$. This value allowed the determination of the concentration of free $\mathrm{Mn}^{2+}$ ions in the supernatant of the GNP-Dex formulations.

\section{Histamine release}

Histamine release was measured using a histamine enzyme-linked immunosorbent assay kit (\#IB89128, Immuno-Biological Laboratories Inc, Minneapolis, MN, USA) on heparinized whole human blood (10761 WB-SHFI, BioChemed Services, Inc, Winchester, VA, USA). The assay was performed according to the protocol provided by the supplier. GNP-Dex solutions at concentrations of 0.1 , 1.0 , and $10.0 \mathrm{mg} / \mathrm{mL}(200 \mu \mathrm{L})$ and control $(200 \mu \mathrm{L})$ (provided with the kit) were first incubated with blood $(200 \mu \mathrm{L})$ at $37^{\circ} \mathrm{C}$ for 60 minutes. The samples were centrifuged at $700 \times g$ for 10 minutes and $50 \mu \mathrm{L}$ of supernatant from each sample was transferred into a reaction plate (provided with the kit) for acylation. In the reaction plate, the samples were incubated with $25 \mu \mathrm{L}$ of acylation reagent (to convert any released histamine into $\mathrm{N}$-acylhistamine) for 45 minutes 
at room temperature. Acylated controls and test solutions (GNP-Dex) (25 $\mu \mathrm{L}$ each) were incubated with histamine antiserum $(100 \mu \mathrm{L})$ in histamine microtiter strips (provided with the kit, with solid-phase histamine bound to the wells) overnight at $4^{\circ} \mathrm{C}$. The following day, after discarding the contents of the well, and rinsing the well with wash buffer (provided with the kit), the wells were treated with $100 \mu \mathrm{L}$ of enzyme conjugate at room temperature for 30 minutes. Next, the contents of the wells were again discarded, and each well was rinsed with wash buffer. A total of $100 \mu \mathrm{L}$ of stop solution (provided with the kit) was added in the wells, and the absorbance readings were taken at $450 \mathrm{~nm}$ with reference wavelength of $630 \mathrm{~nm}$, using an enzyme-linked immunosorbent assay reader (Infinite M200, Tecan Group Ltd).

\section{Relaxivity}

The longitudinal $\left(T_{1}\right)$ relaxation time of $250 \mu \mathrm{L}$ GNP-Dex solutions at different concentrations $(0.4,10.0,20.0,50.0$, and $100.0 \mathrm{mg} / \mathrm{mL}$ ) was measured at room temperature using a relaxometer (iSpin-NMR ${ }^{\mathrm{TM}}$; SpinCore Technologies, Inc., Gainesville, FL, USA) with a $0.47 \mathrm{~T}$ (21.42 MHz resonance frequency) magnetic field. Samples were placed in a clean $8 \mathrm{~mm}$ diameter nuclear magnetic resonance tube (Norell, Inc., Landisville, NJ, USA). The $T_{1}$ measurements were made using an inversion recovery sequence, where inversion time was varied in 12 steps between 0.5 and 5,000.0 milliseconds. The plot of relaxation rate $\left(1 / T_{1}\right.$ in $\mathrm{s}^{-1}, \mathrm{y}$-axis $)$ versus concentration ( $\mathrm{mM}$ of $\mathrm{Mn}^{2+}$, $\mathrm{x}$-axis) was fit to a linear least-square regression line. The slope of this line provided the relaxivity $r_{1}$ value of the GNP-Dex. As described earlier, the $\mathrm{Mn}^{2+}$ ion concentration was measured by ICP-MS.

\section{Magnetic resonance (MR) phantom imaging}

The MRI phantoms were prepared at GNP-Dex concentrations of $7.800,3.900,1.900,0.780,0.390$, and $0.015 \mathrm{mg} / \mathrm{mL}$ in DDI water. Dextran solution $(4.68 \mathrm{mg} / \mathrm{mL})$ and DDI water were used as controls. $T_{1}$-weighted MRI using spin-echo sequence was performed using a $1.5 \mathrm{~T}$ clinical GE Healthcare scanner (carried out at Stony Brook University Hospital, Stony Brook, NY, USA). The slice thickness was set to $3 \mathrm{~mm}$, in plane resolution $2.56 \mathrm{pixel} / \mathrm{mm}$, acquisition time 115.2 seconds and number of averages was 1 . The echo time (TE) and repetition time (TR) were set at 10 and 800 milliseconds, respectively. The field of view was set at $100 \times 100 \mathrm{~mm}$ and the flip angle was $90^{\circ}$.

\section{Results and discussion}

The overall objectives of the studies reported were to synthesize and characterize water-soluble graphene nanoplatelet formulations that are stable at high concentrations in biological media and blood, and to characterize key in vitro physicochemical properties of the water-soluble GNPs based on US FDA guidelines and investigations performed on other MRI CAs during their translation into clinic..$^{9-13}$ The hydrophobic GNPs were non-covalently functionalized with dextran, since previous reports show that it imparts good water solubility to graphene nanoparticles. ${ }^{14}$ Additionally, dextran has been used for a number of biomedical applications, including the development of the experimental $\mathrm{Gd}^{3+}$-based ${ }^{15}$ and clinical iron oxide-based MRI CAs. ${ }^{16}$ Furthermore, dextran is nonfouling, ${ }^{17}$ could prevent nonspecific interactions and may prolong blood circulation half-life in vivo ${ }^{15}$ - essential features for potential advanced MRI applications such as blood pool imaging. Concentrations up to $100 \mathrm{mg} / \mathrm{mL}$ were used in the studies since future in vivo preclinical safety and efficacy studies would require the administration of GNP-Dex at high dosages (up to possibly $500 \mathrm{mg} / \mathrm{kg}$ body weight of the animal) to determine the lethal and therapeutic dosages. Our estimates (see Calculation of the dose in the Supplementary materials section) indicate that to achieve these in vivo dosages, stock nanoparticle solutions with concentration as high as $100 \mathrm{mg} / \mathrm{mL}$ will be needed. For some physicochemical characterization studies, concentrations between 0.1 and $10.0 \mathrm{mg} / \mathrm{mL}$ were used, which correspond to their steady-state equilibrium concentration in the blood (volume $=12-13 \mathrm{~mL}$ ) of a rodent (weight $\sim 200 \mathrm{~g}$ ) after the first pass, if the GNP-Dex formulations are injected intravenously at dosages between 1 and $500 \mathrm{mg} / \mathrm{kg}$.

Figure 1 shows the TEM and atomic force microscopy (AFM) images of GNP-Dex, and provides the formulation's structural and morphological information. The low- and high-resolution TEM images (Figure 1A and B) show that GNP-Dex are disc-shaped nanoparticles with a coil-like dextran structure uniformly coating the GNPs. The size of the GNP-Dex complex, determined by the analysis of the TEM and the AFM images (Figure 1C and D) was $\sim 100-120 \mathrm{~nm}$. Further, the thickness of the GNP-Dex complex determined by AFM was $\sim 3-4 \mathrm{~nm}$.

Figure 2 shows the TGA spectrum of the GNP-Dex formulation. Also included for comparison are TGA spectra of GNPs and dextran. The TGA spectra of the GNPs show a weight loss of $10 \%$ between $10^{\circ} \mathrm{C}$ and $150^{\circ} \mathrm{C}$ due to the loss of adsorbed moisture. The weight loss of $20 \%$ between $150^{\circ} \mathrm{C}$ and $200^{\circ} \mathrm{C}$ can be attributed to the pyrolysis of carboxyl or hydroxyl groups. ${ }^{18}$ The dextran curve exhibits a $80 \%-90 \%$ weight loss between $300^{\circ} \mathrm{C}$ and $350^{\circ} \mathrm{C}$, which is the characteristic decomposition temperature of 

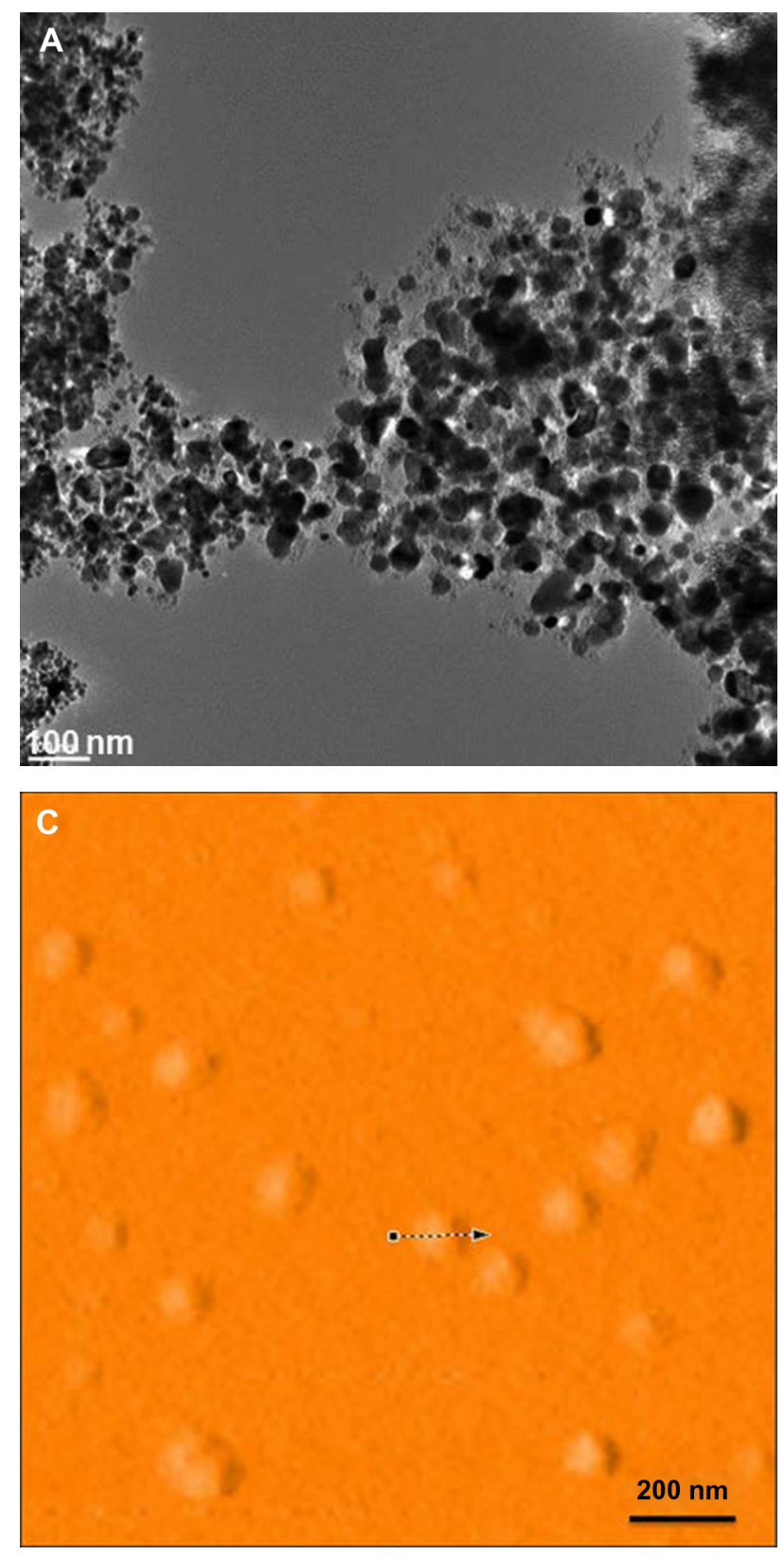

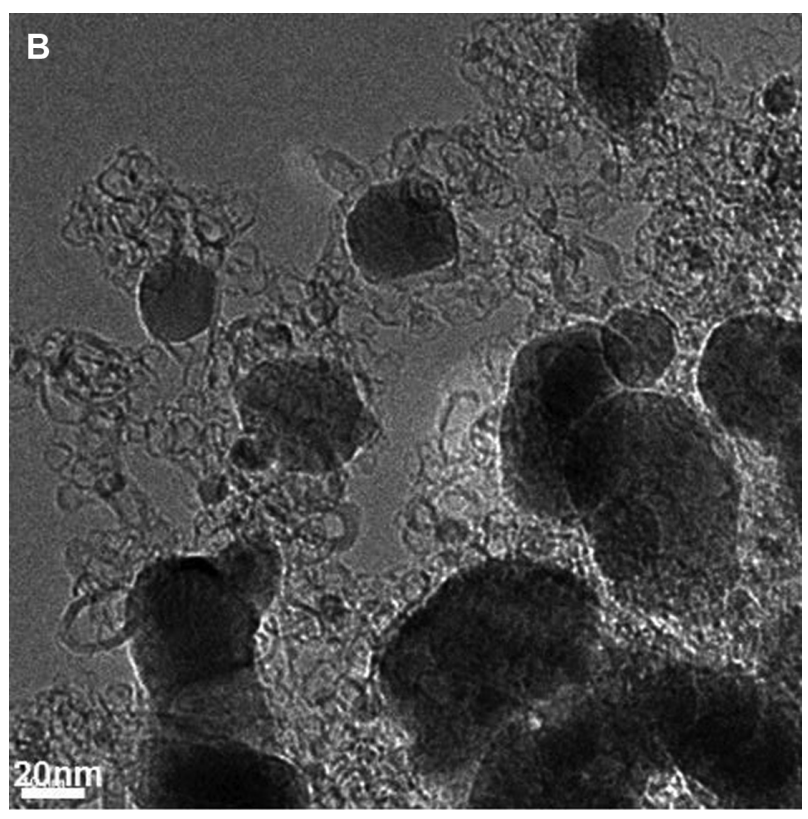

D Topography - section

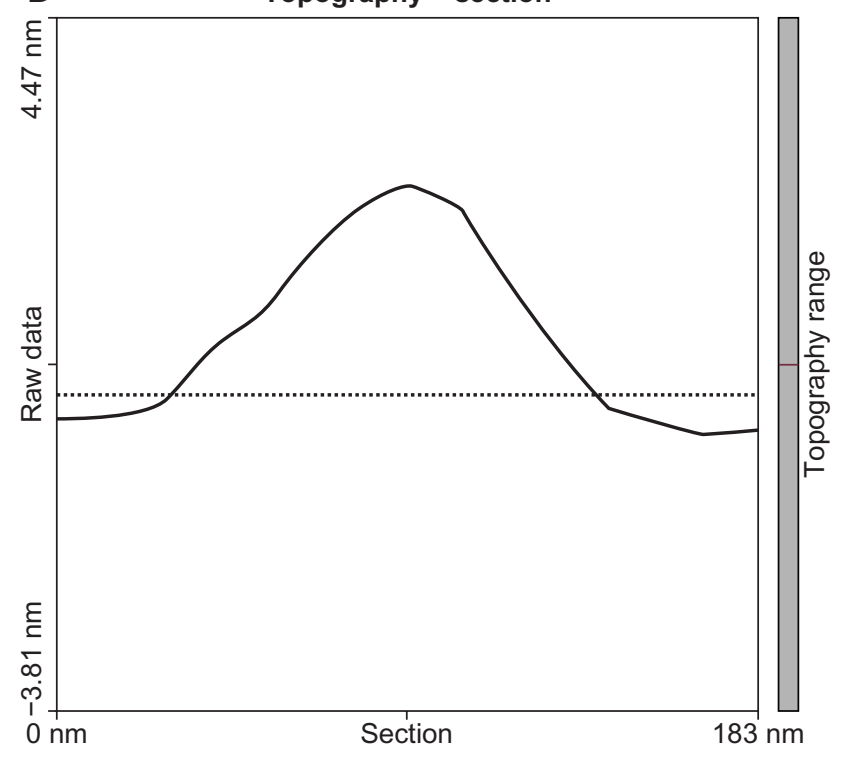

Figure I Representative (A) low-magnification and (B) higher magnification transmission electron microscope images of GNP-Dex; (C) atomic force microscope (AFM) image of graphene nanoplatelets intercalated with manganese $\left(\mathrm{Mn}^{2+}\right)$ ions, functionalized with dextran (GNP-Dex). Arrow tracks the thickness profile of the GNP-Dex nanoparticle. (D) AFM thickness profile of GNP-Dex.

the polysaccharides. ${ }^{19}$ Comparing the thermogram of GNPDex with those of GNPs and dextran gives information about the formulation's composition and chemical modifications. The thermogram of GNP-Dex shows $10 \%$ weight loss at $100^{\circ} \mathrm{C}$ due to loss of moisture. The $10 \%$ weight loss of GNP-Dex in the region between $150^{\circ} \mathrm{C}$ and $200^{\circ} \mathrm{C}$ is due to loss of the labile oxygen-containing groups..$^{18}$ This value is lower than the \% weight loss observed for the GNPs in this region, which suggests partial reduction of the GNPs during the functionalization with dextran. The $40 \%$ weight loss between $250^{\circ} \mathrm{C}$ and $350^{\circ} \mathrm{C}$ indicates the presence of the dextran, and implies that GNP-Dex contains dextran at $40 \%$ by weight.

Figure 3 shows digital photographs of GNP-Dex solutions at $0.4,10.0,20.0,50.0$, and $100.0 \mathrm{mg} / \mathrm{mL}$ concentrations (containing mannitol) at $0,2,4$, and 24 hours after preparation of the solutions. As is evident in the images, the solutions at all concentrations were stable for up to 4 hours. At 24 hours, the GNP-Dex solution at a concentration of $100 \mathrm{mg} / \mathrm{mL}$ separated out. However, this could be easily and uniformly re-dispersed by shaking it gently. An important consideration during in vivo administration of GNP-Dex 


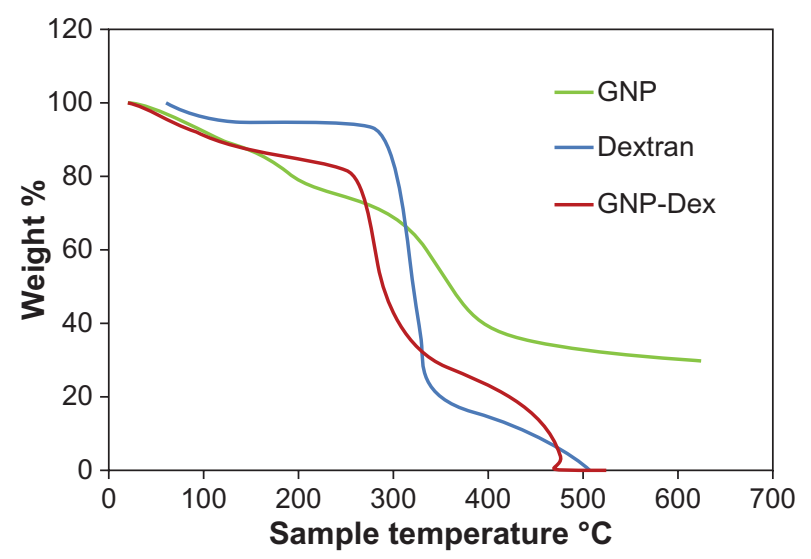

Figure 2 Representative thermogravimetric analysis (TGA) curve of graphene nanoplatelets, dextran, and graphene nanoplatelets intercalated with manganese $\left(\mathrm{Mn}^{2+}\right)$ ions, functionalized with dextran (GNP-Dex).

formulations is that they should remain stable long enough for the dose to be poured out and injected. ${ }^{20}$ In general, settling is considered a significant issue if the solute cannot be easily and uniformly re-dispersed. ${ }^{20}$ The results indicate that, provided the GNP-Dex formulations at various concentrations are prepared fresh and administered immediately, or solutions (especially at very high concentrations) kept for an extended period of time are gently shaken, they are suit-

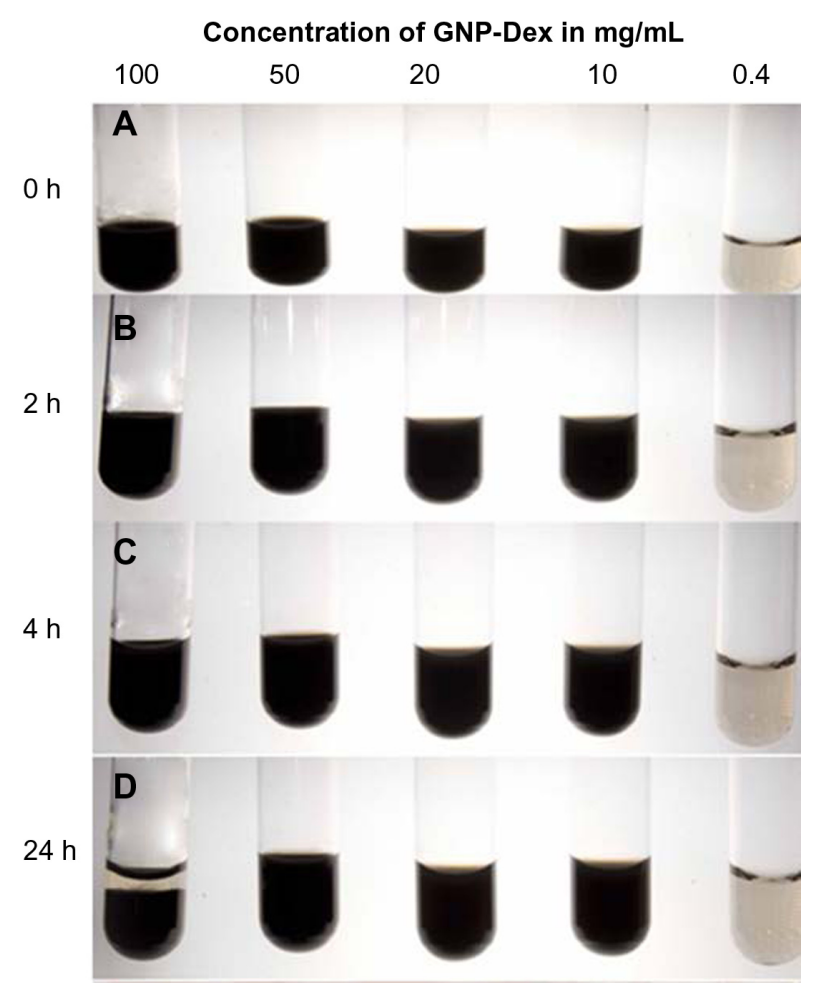

Figure 3 Digital images of vials containing graphene nanoplatelets intercalated with manganese $\left(\mathrm{Mn}^{2+}\right)$ ions, functionalized with dextran (GNP-Dex) in water (with mannitol) at 100.0, 50.0, 20.0, 10.0, $0.4 \mathrm{mg} / \mathrm{mL}$ concentrations at (A) 0 hour (h), (B) 2 hours, (C) 4 hours, and (D) 24 hours after preparing the solutions. able as stock solutions for in vivo administration. The higher stability of the formulations in water can be attributed to the uniform coating of dextran on GNPs, which counteracts the hydrophobic forces exerted by the GNPs that can lead to aggregation.

To the best of our knowledge, this is the highest level of solubility that has been achieved for any water-solubilized graphene nanoparticle. An MRI CA needs to exhibit excellent solubility even at high concentrations to achieve the dose required for bolus injection (the clinical dose of a $\mathrm{Gd}^{3+}$ chelate-based MRI CA can be between 1 and $100 \mathrm{mg} / \mathrm{kg}^{21}$ ). Additionally, an important consideration is that the watersolubilizing moieties need to be biocompatible. Different covalent and non-covalent functionalization approaches have been employed to water-solubilize graphene nanoparticles. ${ }^{6}$ Graphene nanoparticles have been covalently functionalized with carboxylic acid, hydroxyl, ${ }^{22}$ poly-L-lysine, ${ }^{23}$ and non-covalently functionalized with synthetic polymer polyethylene glycol ${ }^{6}$ or Pluronic F-127. ${ }^{7}$ The maximum solubility reported for these functionalization approaches has been between 1 and $2 \mathrm{mg} / \mathrm{mL}$. Recently, graphene nanoparticles have been covalently conjugated with the natural polymer dextran with a maximum water solubility of $1 \mathrm{mg} / \mathrm{mL} \cdot{ }^{14,24,25}$ At the concentration of $1 \mathrm{mg} / \mathrm{mL}$, the volume needed to be injected for in vivo small animal safety studies to achieve the above dosages (1-100 mg/kg) would be up to $1.56 \%-156.25 \%$ of the total blood volume (estimated based on a $200 \mathrm{~g}$ rat with total blood volume of $\sim 12.8 \mathrm{~mL}$; see Calculation of the dose in the Supplementary materials section) or $1.4 \%-140.0 \%$ of the total blood volume (5 L of an adult human weighing $70 \mathrm{~kg}$; see the Supplementary materials section), which is not feasible at higher doses. The GNP-Dex formulations not only show substantially greater solubility than the other approaches but also stability in physiologically relevant fluids. Additionally, at high concentrations (eg, 50-100 mg/mL), GNP-Dex can be injected at 4\%-8\% of the rat blood volume to achieve bolus dosages between 50 and $500 \mathrm{mg} / \mathrm{kg}$, which is feasible.

Tables 1-4 show the results of assessments of the key physicochemical properties, osmolality, viscosity, partition coefficient, protein binding, histamine release, and relaxivity. Osmolality of an MRI CA is an important property that depends on the solute concentration. Adverse effects of contrast media with low or high osmolality (compared with blood osmolality) include changes in the circulatory system such as vasodilation, vasoconstriction, crenation of red blood cells, and release of vasopressin. ${ }^{9,26}$ Clinically, these changes manifest as sensations of warmth, heat, and pain at 
Table I Osmolality of graphene nanoplatelets intercalated with manganese $\left(\mathrm{Mn}^{2+}\right)$ ions, functionalized with dextran (GNP-Dex) in distilled deionized water before and after the addition of mannitol

\begin{tabular}{llc}
\hline $\begin{array}{l}\text { Concentration } \\
(\mathrm{mg} / \mathrm{mL})\end{array}$ & $\begin{array}{l}\text { Osmolality } \\
\text { (mOsm/kg) before } \\
\text { addition of mannitol } \\
\text { (mean } \pm \text { SD) }\end{array}$ & $\begin{array}{l}\text { Osmolality } \\
\text { (mOsm/kg) after } \\
\text { addition of mannitol } \\
\text { (mean } \pm \text { SD) }\end{array}$ \\
\hline 100.0 & $33.0 \pm 0.5$ & $306.7 \pm 1.5$ \\
50.0 & $17.0 \pm 0.3$ & $296 \pm 0.0$ \\
20.0 & $5.0 \pm 0.2$ & $297.7 \pm 0.6$ \\
10.0 & $5.0 \pm 0.1$ & $289.7 \pm 1.5$ \\
0.4 & $3.0 \pm 0.0$ & $303 \pm 0.0$ \\
\hline
\end{tabular}

Abbreviation: SD, standard deviation.

the site of injection. Table 1 displays the osmolality values of GNP-Dex solutions at concentrations between 0.4 and $100.0 \mathrm{mg} / \mathrm{mL}$ in the absence and presence of mannitol. The results show that the osmolality of the GNP-Dex increases with an increase in concentration. However, the GNP-Dex formulations are hypo-osmolar at all concentrations (normal blood osmolality $=285-295 \mathrm{mOsm} / \mathrm{kg}$ of $\left.\mathrm{H}_{2} \mathrm{O}\right) .{ }^{27}$ The addition of mannitol increased the osmolality values for all GNPDex concentrations, and these formulations were within the osmolality range observed for normal blood. Mannitol is an additive routinely used in osmotherapy as a diuretic agent, and has been employed for the clinical iron oxide-based MRI CA Feridex IV ${ }^{\circledR}$ (Bayer Healthcare Pharmaceuticals Inc, Wayne, $\mathrm{NJ}$, USA) to maintain its osmolality at $340 \mathrm{mOsm} / \mathrm{kg} .{ }^{16,28}$

The viscosity of MRI CAs depends on their chemical structure, concentration, and temperature. ${ }^{29}$ Table 2 shows the viscosity of the GNP-Dex solutions at concentrations between 0.4 and $100.0 \mathrm{mg} / \mathrm{mL}$ at $37^{\circ} \mathrm{C}$. The viscosity values at all concentrations were less than or within the range of blood viscosity (between 3 and $4 \mathrm{cP}$ at $37^{\circ} \mathrm{C}$ ). The viscosity of the GNP-Dex solutions was also dependent on shear rate at all concentrations, which suggests that GNP-Dex solution at these concentrations behaves as a non-Newtonian fluid, similar to whole blood. ${ }^{28}$ The viscosities of the MRI CA solutions affect their rate of injection and in vivo flow characteristics.

Table 2 Viscosity of graphene nanoplatelets intercalated with manganese $\left(\mathrm{Mn}^{2+}\right)$ ions, functionalized with dextran (GNP-Dex) at different concentrations at $37^{\circ} \mathrm{C}$

\begin{tabular}{llll}
\hline $\begin{array}{l}\text { Concentration } \\
(\mathbf{m g} / \mathbf{m L})\end{array}$ & $\begin{array}{l}\mathbf{1 0 0} \mathbf{~ r p m} \\
\text { (cP) }\end{array}$ & $\begin{array}{l}\mathbf{5 0} \mathbf{~ r p m} \\
\mathbf{( c P )}\end{array}$ & $\begin{array}{l}\mathbf{2 0} \mathbf{~ r p m} \\
\mathbf{( c P )}\end{array}$ \\
\hline 100.0 & $\mathrm{ND}$ & 2.45 & 4.46 \\
50.0 & 2.37 & 3.68 & 2.82 \\
20.0 & 1.35 & 1.39 & 1.69 \\
10.0 & 1.60 & 2.10 & $\mathrm{ND}$ \\
0.4 & 2.30 & 3.80 & $\mathrm{ND}$ \\
\hline
\end{tabular}

Abbreviation: ND, not determined.
Table 3 Physicochemical properties of graphene nanoplatelets intercalated with manganese $\left(\mathrm{Mn}^{2+}\right)$ ions, functionalized with dextran (GNP-Dex)

\begin{tabular}{lll}
\hline Parameter & Results & Condition \\
\hline $\begin{array}{l}\text { Partition coefficient } \\
\left(\text { log } P_{\text {ow }}\right)\end{array}$ & -0.18 & $20 \mathrm{mg} / \mathrm{mL}$, at $25^{\circ} \mathrm{C}$ \\
Protein binding & $<$ LOD & $0.1,1.0$, \\
& $(0.001 \mathrm{mg} / \mathrm{mL})$ & $10.0 \mathrm{mg} / \mathrm{mL}$ at $37^{\circ} \mathrm{C}$ \\
Released free & $<$ LOD $(0.01 \mu \mathrm{M})$ & $20.0,50.0$, \\
Mn ${ }^{2+}$ ions & & $100.0 \mathrm{mg} / \mathrm{mL}$ at $37^{\circ} \mathrm{C}$ \\
Histamine release & $<$ negative control & $0.1,1.0$, \\
& & $10.0 \mathrm{mg} / \mathrm{mL}$ at $25^{\circ} \mathrm{C}$ \\
\hline
\end{tabular}

Abbreviation: LOD, limit of detection.

MRI CAs with viscosity values higher than that of blood typically cannot be injected intravenously as a bolus. They need to be injected at a slower rate. Higher viscosity MRI CAs have been shown to cause deleterious effects on renal perfusion and renal output. ${ }^{30}$ However, these effects can be mitigated by warming up the MRI CA prior to its in vivo administration to lower its viscosity. ${ }^{30}$ Studies show that MRI CAs with high viscosities (greater than that of blood) affect the intrinsic and extrinsic coagulation cascade pathways, platelet function and vascular endothelial function to a certain extent, ${ }^{28}$ while low-viscosity MRI CAs (with viscosities lower than that of blood) do not substantially affect these hemodynamic parameters. ${ }^{28}$

The partition coefficient $\left(\mathrm{P}_{\text {ow }}\right)$ of an MRI CA provides a measure of its hydrophilicity and hydrophobicity. ${ }^{9}$ In turn, these properties affect their in vivo biodistribution profile. ${ }^{31}$ The partition coefficient of GNP-Dex at concentrations 0.1, 1.0 , and $10.0 \mathrm{mg} / \mathrm{mL}$ was calculated to be -0.18 (Table 3 ). This value is comparable to the values reported for clinical MRICAs developed as extravascular agents (Table 5). Visual analysis also showed that the majority of the GNP-Dex separated into the aqueous phase or stayed at the aqueous-octanol interface and could not be detected in the octanol phase. No UV-Vis spectra

Table $4 T_{\text {, }}$ (relaxation time) values of graphene nanoplatelets intercalated with manganese $\left(\mathrm{Mn}^{2+}\right)$ ions, functionalized with dextran solutions and distilled deionized (DDI) water at different concentration and corresponding $\mathrm{Mn}^{2+}$ ion concentration

\begin{tabular}{lcl}
\hline $\begin{array}{l}\text { Concentration } \\
(\mathbf{m g} / \mathbf{m L})\end{array}$ & $\begin{array}{l}T_{1} \text { time }(\mathbf{m s}) \\
(\mathbf{m e a n} \pm \mathbf{S D})\end{array}$ & $\begin{array}{l}\mathbf{M n}^{2+} \text { concentration } \\
(\mathbf{m M})(\mathbf{m e a n} \pm \mathbf{S D})\end{array}$ \\
\hline 100.0 & $10.51 \pm 0.27$ & 1.038 \\
50.0 & $24.28 \pm 1.34$ & 0.273 \\
20.0 & $67.64 \pm 0.42$ & 0.271 \\
10.0 & $108.27 \pm 1.94$ & 0.138 \\
0.4 & $1,993.86 \pm 227.38$ & 0.006 \\
DDI water & $5,672.92 \pm 282.45$ & 0.000 \\
\hline
\end{tabular}

Abbreviation: SD, standard deviation. 
Table 5 Comparison of the physicochemical properties of graphene nanoplatelets intercalated with manganese $\left(\mathrm{Mn}^{2+}\right)$ ions, functionalized with dextran (GNP-Dex) with US Food and Drug Administration (FDA)-approved magnetic resonance imaging contrast agent (MRI CA)

\begin{tabular}{|c|c|c|c|c|c|}
\hline $\begin{array}{l}\text { US FDA-approved } \\
\text { MRI CA }\end{array}$ & $\begin{array}{l}\text { Osmolality } \\
\text { (mOsm/kg of water) }\end{array}$ & $\begin{array}{l}\text { Viscosity } \\
(\mathrm{cP}) \text { at } 37^{\circ} \mathrm{C}\end{array}$ & $\begin{array}{l}\text { Partition coefficient } \\
\left(\log P_{\text {ow }}\right)\end{array}$ & Protein binding & $\begin{array}{l}\text { Relaxivity }\left(r_{1}\right) \\
\mathrm{mM}^{-1} \mathrm{~s}^{-1} \text { at } 0.47 \mathrm{~T}^{8} \\
\end{array}$ \\
\hline ProHance $^{41}$ & 630 & 1.3 & -3.6800 & None & 3.1 \\
\hline MultiHance ${ }^{\circledR 42}$ & I,970 & 5.3 & 0.0016 & $<5 \%$ & 4.2 \\
\hline Magnevist ${ }^{\circledR 43}$ & 1,960 & 2.9 & -5.4000 & None & 3.4 \\
\hline Omniscan ${ }^{\mathrm{TM}} 46$ & 789 & $\mathrm{I} .4$ & -2.1000 & None & 3.5 \\
\hline Teslascan $^{44}$ & 290 & 0.7 & -5.6200 & $\begin{array}{l}\text { Fodipir chelate (negligible), } \\
\text { free } \mathrm{Mn}^{2+} \text { ions }(27 \%)\end{array}$ & 1.5 \\
\hline Optimark ${ }^{\text {TM } 45}$ & 1,110 & 2.0 & -8.2200 & None & 4.2 \\
\hline GNP-Dex & 290 & 2.4 & -0.1800 & None & 92 \\
\hline
\end{tabular}

Notes: ProHance, Bracco Diagnostics Inc. Princeton, NJ, USA; MultiHance ${ }^{\circledast}$, Bracco Diagnostics Inc.; Magnevist ${ }^{\circledast}$, Bayer Schering Pharma, Berlin-Wedding, Germany; Omniscan $^{\text {TM }}$, GE Healthcare, Little Chalfont, UK; Teslascan, GE Healthcare; Optimark ${ }^{\mathrm{TM}}$, Mallinckrodt Inc., St Louis, MO, USA.

of the GNP-Dex in octanol phase could be obtained, indicating that the nanoparticles, if present, were below the detection limit of the instrument. The results indicate that most of the GNP-Dex nanoparticles were hydrophilic, and preferentially accumulate in the aqueous phase, and a small fraction were amphiphilic, accumulating at the water-octanol interface.

The propensity of MRI CAs to bind to protein could affect their targeting capability, pharmacokinetics, and relaxivity. ${ }^{9,31}$ Equilibrium dialysis of an MRI CA with the protein HSA followed by BCA protein assay is one of the most widelyaccepted methods for studying protein-drug interaction. ${ }^{32,33}$ The results (Table S1) of the protein binding, summarized in Table 4, show that HSA protein was not bound to the GNPDex formulations. The lack of protein binding onto GNP-Dex can be attributed to the non-fouling property of dextran, ${ }^{17}$ and suggests that it could prevent nonspecific interactions.

Thermal stability of the intercalated $\mathrm{Mn}^{2+}$ ions is a key physiochemical property. It was important to determine if the intercalated $\mathrm{Mn}^{2+}$ ions dissociate from the GNP-Dex nanoparticles and were present as free $\mathrm{Mn}^{2+}$ ions under physiological temperatures. The $\mathrm{Mn}^{2+}$ ion, a natural cellular constituent, functions as a regulatory cofactor for enzymes and receptors. ${ }^{2}$ The normal daily dietary requirement for manganese is $2.7-7.0 \mathrm{mg},{ }^{34}$ and the normal serum level is $0.1 \mu \mathrm{M} .{ }^{35}$ However, prolonged exposure to high concentrations of $\mathrm{Mn}^{2+}$ ions has been reported to be toxic, and results in "manganism," a Parkinson-like neurological disorder, and cardiac dysfunction. ${ }^{2,36}$ Therefore, it was critical to investigate whether the intercalated $\mathrm{Mn}^{2+}$ ions, at the physiological temperature of $37^{\circ} \mathrm{C}$, dissociate from GNP-Dex nanoparticles. The thermal stability experiments (Table S2 and summarized in Table 4) with GNP-Dex solutions, for 3 or 24 hours, at 20, 50, and $100 \mathrm{mg} / \mathrm{mL}$ concentrations, show no presence of free $\mathrm{Mn}^{2+}$ ions (limit of detection $[\mathrm{LOD}]=0.01 \mu \mathrm{M}$ ) at $37^{\circ} \mathrm{C}$. The results indicate that $\mathrm{Mn}^{2+}$ ions present in the GNP-Dex formulation are stable at least short-term ( 24 hours) at simulated physiological temperature. Typically, clinical first pass or blood pool CAs have been reported to have average blood half-lives of 1.5 hours, and $>95 \%$ of the CA is excreted in 24 hours. ${ }^{37}$ Thus, taken together with this information, the reported results suggest that provided the in vivo blood half-life and the elimination rate of the GNP-Dex formulations are similar, the intercalated $\mathrm{Mn}^{2+}$ ions should be stable within the graphene nanoplatelets in vivo. However, the long-term ( $>24$ hours) in vitro and in vivo thermal stability of these formulations still needs to be determined before a firm conclusion can be drawn.

It is well documented that MRI CAs can evoke adverse allergic reactions with symptoms that can include urticaria or hives-like inflammation as well as swelling and reddening of the tissues, watery eyes, runny nose, migraine headaches, nausea, vomiting, laryngospasm, and bronchospasm. ${ }^{38-40}$ Histamine, a naturally occurring biomolecule found in vivo, is released as a response to allergic reactions ${ }^{40}$ and is considered a good marker to evaluate the propensity of an MRI CA to elicit an allergic response. Our results show no significant release of histamine at GNP-Dex concentrations of 0.1, 1.0, and $10.0 \mathrm{mg} / \mathrm{mL}$ compared with the control (Table S3). These results are encouraging since histamine can also stimulate fibroblast proliferation and collagen production, and can play an important role in skin fibrosis - a major symptom associated with nephrogenic systemic fibrosis ${ }^{40}$ Studies on $\mathrm{Gd}^{3+}$ - and $\mathrm{Mn}^{2+}$-chelate MRI CAs indicate that, at physiologically relevant plasma concentrations $(0.1-10.0 \mathrm{mM})$, they do not exhibit a propensity to release histamine.$^{40}$ At higher dosages (50-150 mM), $\mathrm{Gd}^{3+}$-chelate complexes have been shown to release histamine in vitro. ${ }^{40}$

Relaxivity is an important measure of efficacy for $T_{1}$ MRI CAs. ${ }^{1}$ Our previous results show that the $r_{2} / r_{1}$ ratio 
for water-solubilized GNP solutions is 2.2, which is in the range reported for $\mathrm{Mn}^{2+}$ - or $\mathrm{Gd}^{3+}$-chelate complexes $\left(r_{2} / r_{1}\right.$ 1.0-2.5) $T_{1}$ MRI CAs. ${ }^{7,8}$ The ratio is also lower than the iron oxide-functionalized graphene nanoparticles $\left(r_{2} / r_{1} \sim 10\right)$ $T_{2}$ MRI CAs. ${ }^{7}$ Thus, the GNP-Dex formulations would be more suitable as a $T_{1}$ MRI CA. Table 4 shows $T_{1}$ relaxation time at $0.47 \mathrm{~T}$ (21.42 $\mathrm{MHz}$ proton Larmor frequency) at different doses of GNP-Dex. Also included are the $\mathrm{Mn}^{2+}$ ion concentrations (in $\mu \mathrm{M}$ ) for each GNP-Dex dose. The relaxivity value calculated from the plot (Figure $4 \mathrm{~A}$ ) of $1 / T_{1}$ versus $\mathrm{Mn}^{2+}$ ion concentration is $92.2 \mathrm{mM}^{-1} \mathrm{~s}^{-1}$. MR phantom imaging further corroborates this evaluation. Figure 4B displays representative $T_{1}$-weighted MR images of GNP-Dex solutions at different concentrations $(0.78-7.8 \mathrm{mg} / \mathrm{mL})$ and the corresponding $\mathrm{Mn}^{2+}$ ion concentration $(0.22-90.88 \mu \mathrm{M})$ for each dose. These concentrations correspond to the equilibrium plasma concentration in rodents (average weight $=200 \mathrm{~g}$ ) if the GNP-Dex is injected at doses between 1 and $500 \mathrm{mg} / \mathrm{kg}$.
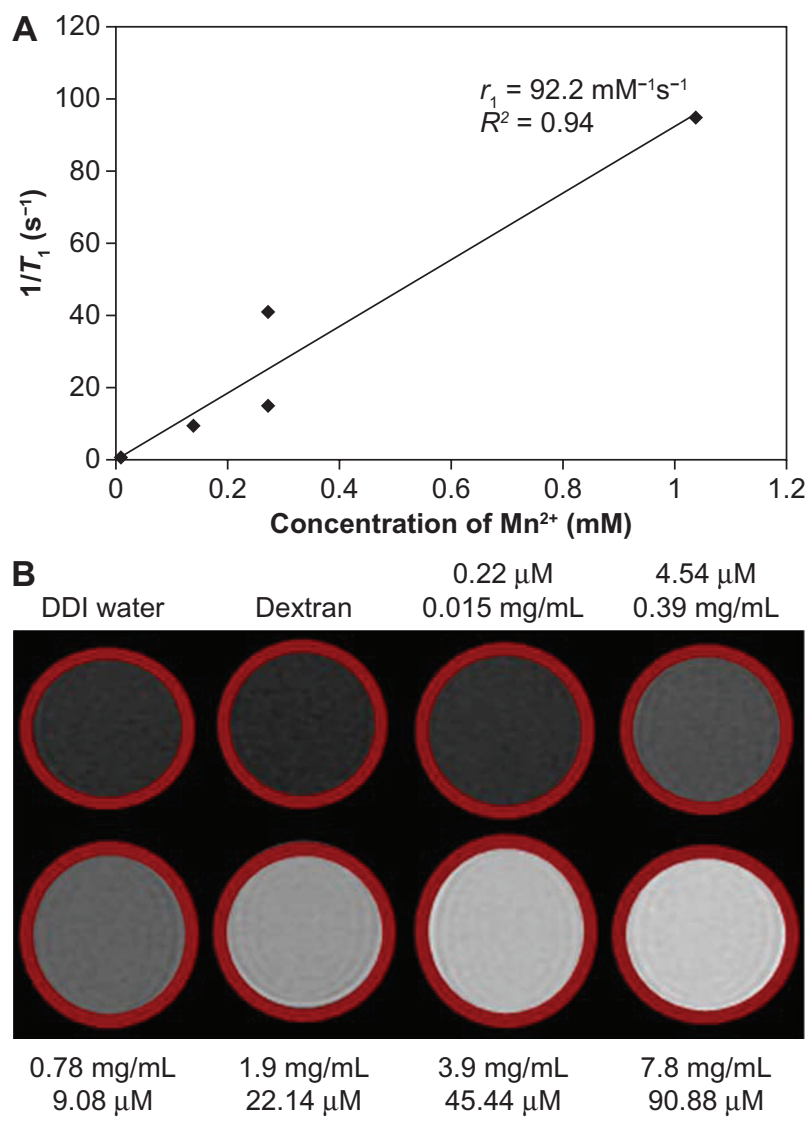

Figure 4 (A) Plot of relaxation rate $\left(\mathrm{I} / T_{1}\right)$ versus $\mathrm{Mn}^{2+}$ ions concentration fit to a linear regression line. (B) $T_{1}$-weighted magnetic resonance phantom images of graphene nanoplatelets intercalated with manganese $\left(\mathrm{Mn}^{2+}\right)$ ions, functionalized with dextran (GNP-Dex), distilled deionized (DDI) water, and dextran solution obtained using a $1.5 \mathrm{~T}$ clinical scanner. Row I (left to right): DDI water and dextran solution in water at $4.68 \mathrm{mg} / \mathrm{mL}, \mathrm{GNP}$-Dex at concentrations 0.015 and $0.390 \mathrm{mg} / \mathrm{mL}$. Row 2 (left to right): GNP-Dex at $0.78,1.90,3.90$, and $7.80 \mathrm{mg} / \mathrm{mL}$. For each GNP-Dex concentration, the concentration of $\mathrm{Mn}^{2+}$ ions is also shown in $\mu \mathrm{M}$.
Also included as baseline controls are $T_{1}$-weighted images of DDI water and dextran solution. The images clearly show a substantial dose-dependent contrast enhancement compared with the baseline controls. The plasma concentration of the $\mathrm{Gd}^{3+}$ chelate-based CA at a clinical dose of $0.1 \mathrm{mmol} / \mathrm{kg}$ in a $200 \mathrm{~g}$ rat would be $1.5 \mathrm{mM}$, which is 17 times higher than the highest concentrations of $\mathrm{Mn}^{2+}(90.88 \mu \mathrm{M})$ in GNP-Dex solution (see Calculation of the plasma concentration for relaxivity in the Supplementary materials section). This suggests that GNP-Dex can provide similar MR contrast at lower dosages.

Table 5 compares the values of various physiochemical properties of the GNP-Dex formulation with other US FDAapproved MRI CAs. ${ }^{41-46}$ Most Gd $^{3+}$ chelate-based clinical MRI CAs are hyper-osmolar, ranging in value from 630 to $1,970 \mathrm{mOsm} / \mathrm{kg}{ }^{41-46}$ while the $\mathrm{Mn}^{2+}$ chelate-based MRI CA Teslascan and iron oxide nanoparticle-based MRI CA Feridex are iso-osmolar. ${ }^{16}$ In the presence of mannitol, the GNP-Dex formulations were found to be iso-osmolar over a wide range of concentrations $(0.1-100.0 \mathrm{mg} / \mathrm{mL})$. The viscosity values of 1.3-4.4 cP for GNP-Dex formulations are within the range measured for blood and are similar to those of other MRI CAs. Comparison of the partition coefficient value of -0.18 for the GNP-Dex formulation with those of clinically approved MRI CAs indicates that the GNP-Dex formulation could be less hydrophilic than Magnevist, ProHance ${ }^{\circledR}$ (Bracco Diagnostics Inc., Princeton, NJ, USA), Omniscan ${ }^{\mathrm{TM}}$, Teslascan, and Optimark ${ }^{\mathrm{TM}}$ (Mallinckrodt, Hazelwood, MO, USA), and more hydrophilic than MultiHance ${ }^{\circledR}$ (Bracco Diagnostics Inc.). Most of the clinical MRI CAs show insignificant protein binding except for MultiHance and Teslascan. MultiHance shows less than 5\% plasma protein binding. ${ }^{42}$ In the case of Teslascan, the chelate fodipir does not bind to the protein; however, the $\mathrm{Mn}^{2+}$ ions, after dissociating from the chelate, show $27 \%$ protein binding in whole human blood in vitro. ${ }^{44}$ The GNP-Dex did not show significant protein binding. The $r_{1}$ relaxivity for US FDA-approved $\mathrm{Gd}^{3+}$ and $\mathrm{Mn}^{2+}$ chelate-based MRI CAs is $2.2-4.5 \mathrm{mM}^{-1} \mathrm{~s}^{-1}$; GNP-Dex has $r_{1}$ relaxivity of $92 \mathrm{mM}^{-1} \mathrm{~s}^{-1}$, which is 20- to 40 -fold greater than those of $\mathrm{Gd}^{3+}$ and $\mathrm{Mn}^{2+}$ chelate-based MRI CAs. ${ }^{8}$ The size of the GNP-Dex suggests that, similar to other macromolecular MRI CAs, ${ }^{47}$ the formulation will be retained in the intravascular compartment, thus may be suitable as a blood pool agent. Future in vivo preclinical MRI studies should provide insights into its potential application. Our previous relaxometric studies on GNPs indicate that multiple structural and molecular dynamic parameters that characterize the water molecule-MRI CA interactions, and 
affect the $T_{1}$ relaxation mechanism, are modulated and are responsible for the observed increase in the relaxivity. ${ }^{48}$ The parameters include the number of water molecules $(q)$ that can simultaneously coordinate with the $\mathrm{Mn}^{2+}$ ions intercalated within the GNPs, the residence lifetime $\left(\tau_{\mathrm{M}}\right)$ of the water molecules coordinated on the $\mathrm{Mn}^{2+}$ ions, and the rotational correlation time $\left(\tau_{\mathrm{R}}\right)$ of the GNPs.

Over the past 10 years, carbon nanostructures such as gadofullerenes (represented as $\mathrm{Gd} @ \mathrm{C}_{60}, \mathrm{Gd} @ \mathrm{C}_{80}$, and $\mathrm{Gd} @ \mathrm{C}_{82}$ ) and gadonanotubes (represented as Gd@UStubes, where "US-tubes" means "ultra-short single-walled carbon nanotubes") that encapsulate $\mathrm{Gd}^{3+}$ metal ions have been proposed as $T_{1}$ CAs for MRI. ${ }^{1,49}$ Even though these MRI CAs show higher relaxivity compared with clinical MRI CAs, none has translated into clinical use. Recent reports also show that administration of clinical $\mathrm{Gd}^{3+}$-based MRI CAs (especially Omniscan) to patients with severe acute or chronic renal insufficiency (glomerular filtration rate $<30 \mathrm{~mL} / \mathrm{min} / 1.73 \mathrm{~m}^{2}$ ), significantly increases their risk for developing nephrogenic systemic fibrosis. ${ }^{4}$ As a result of these findings, the US FDA has restricted their use in patients suffering from renal insufficiency and instructed manufacturers to include mandatory box warnings and disclose contraindications for this high-risk group on the product labeling of all $\mathrm{Gd}^{3+}$-based MRI CAs. ${ }^{5}$ Recently, manganese has received attention as a possible alternative to gadolinium. Manganese, a natural cellular constituent resembling $\mathrm{Ca}^{2+}$, which often functions as a regulatory cofactor for enzymes and receptors, was one of first elements reported suitable as a CA for MRI. ${ }^{2}$ Manganese toxicity is rare, and has only been reported following long-term exposure to high concentrations, which has resulted in neurological symptoms. ${ }^{2}$ The two $\mathrm{Mn}^{2+}$-based agents - Teslascan and an oral CA containing manganese (II) chloride (Bracco Diagnostics Inc.) - that were approved for clinical use have been discontinued. The synthesis and characterization of the highly water-soluble $\mathrm{Mn}^{2+}$ ion intercalated GNP-Dex formulations, along with the positive results of their key in vitro physiochemical properties opens avenues for further in vitro and in vivo preclinical studies to assess their suitability as a next-generation $T_{1}$ MRI CA with a safety and efficacy profile that can overcome the outlined limitations.

\section{Conclusion}

The GNP-Dex formulation shows very high solubility (up to $100 \mathrm{mg} / \mathrm{mL}$ ) and stability in deionized water and biological buffers. The osmolality of GNP-Dex is lower than that of blood, and can be adjusted to be similar to blood by adding the diuretic mannitol. The viscosities of the GNP-Dex formulations were within the range of blood viscosity. At physiological temperatures $\left(37^{\circ} \mathrm{C}\right)$, GNP-Dex was structurally stable and the intercalated $\mathrm{Mn}^{2+}$ ions did not dissociate for up to 24 hours. Most of the GNP-Dex nanoparticles were hydrophilic, and a small fraction was amphiphilic. At potential therapeutic dosages, GNP-Dex showed very little or no interaction with blood protein HSA, suggesting that they prevent nonspecific adsorption of proteins. Moreover, the formulations did not trigger histamine release in whole human blood, suggesting that they are unlikely to evoke allergic responses. The high $r_{1}$ relaxivity $\left(92 \mathrm{mM}^{-1} \mathrm{~s}^{-1}\right)$ of GNP-Dex allowed significant contrast enhancement of $T_{1}$-weighted MRI phantoms even at modest (nM) concentrations of $\mathrm{Mn}^{2+}$ ions. The in vitro results show that the physicochemical properties of the GNP-Dex were comparable to or better than those of clinically approved MRI CAs. The studies open avenues for further in vitro and in vivo preclinical studies to translate this promising $T_{1}$ MRI CA into clinical use.

\section{Acknowledgments}

This work was sponsored by the Wallace H Coulter Foundation. The authors thank Dr David Hirschberg for his help with performing ICP-MS and Ms Shelagh Zegers for her help with lyophilization.

\section{Disclosure}

The authors declare no conflicts of interest in this work.

\section{References}

1. Sitharaman B, Wilson LJ. Gadofullerenes and gadonanotubes: a new paradigm for high-performance magnetic resonance imaging contrast agent probes. J Biomed Nanotechnol. 2007;3(4):342-352.

2. Pan D, Caruthers SD, Senpan A, Schmieder AH, Wickline SA, Lanza GM. Revisiting an old friend: manganese-based MRI contrast agents. Wiley Interdiscip Rev Nanomed Nanobiotechnol. 2011;3(2):162-173.

3. Ananta JS, Godin B, Sethi R, et al. Geometrical confinement of gadolinium-based contrast agents in nanoporous particles enhances T1 contrast. Nat Nanotechnol. 2010;5(11):815-821.

4. Broome DR. Nephrogenic systemic fibrosis associated with gadolinium based contrast agents: a summary of the medical literature reporting. Eur J Radiol. 2008;66(2):230-234.

5. Bayer HealthCare Pharmaceuticals Inc, Bracco Diagnostics Inc, GE Healthcare, Mallinkrodit Inc Important Drug Warning for Gadoliniumbased Contrast Agents [letter to healthcare professionals]. Bayer HealthCare Pharmaceuticals Inc, Bracco Diagnostics Inc, GE Healthcare, Mallinkrodit Inc; 2007. Available from: http:/www.fda.gov/downloads/ safety/medwatch/safetyinformation/safetyalertsforhumanmedicalprodu cts/ucm154532.pdf. Accessed June 18, 2013.

6. Feng L, Liu Z. Graphene in biomedicine: opportunities and challenges. Nanomedicine (Lond). 2011;6(2):317-324.

7. Paratala BS, Jacobson BD, Kanakia S, Francis LD, Sitharaman B. Physicochemical characterization, and relaxometry studies of micrographite oxide, graphene nanoplatelets, and nanoribbons. PLoS One. 2012;7(6): 38185. 
8. Rohrer M, Bauer H, Mintorovitch J, Requardt M, Weinmann HJ. Comparison of magnetic properties of MRI contrast media solutions at different magnetic field strengths. Invest Radiol. 2005;40(11):715-724.

9. Vogler H, Platzek J, Schuhmann-Giampieri G, et al. Pre-clinical evaluation of gadobutrol: a new, neutral, extracellular contrast agent for magnetic resonance imaging. Eur J Radiol. 1995;21(1):1-10.

10. ICH. Safety pharmacology studies for human pharmaceuticals. Geneva: International Conference on Harmonisation; 2000. Available from: http:// www.ich.org/fileadmin/Public_Web_Site/ICH_Products/Guidelines/ Safety/S7A/Step4/S7A_Guideline.pdf. Accessed July 15, 2013.

11. US FDA. Developing medical imaging drug and biological products part 1: conducting safety assessments. Rockville: US Food and Drug Adminsitration; 2004. Available from: http://www.fda.gov/downloads/ Drugs/.../Guidances/ucm071600.pdf. Accessed July 15, 2013.

12. OECD. OECD guidelines for the testing of chemicals. Paris: Organisation for Economic Co-operation and Development; 2000. Available from: http://www.oecd.org/chemicalsafety/testing/2731134.pdf. Accessed July 15, 2013.

13. Runge VM. Safety of approved MR contrast media for intravenous injection. J Magn Reson Imaging. 2000;12(2):205-213.

14. Zhang S, Yang K, Feng L, Liu Z. In vitro and in vivo behaviors of dextran functionalized graphene. Carbon. 2011;49(12):4040-4049.

15. Sirlin CB, Vera DR, Corbeil JA, Caballero MB, Buxton RB, Mattrey RF. Gadolinium-DTPA-dextran: a macromolecular MR blood pool contrast agent. Academic Radiology. 2004;11(12):1361-1369.

16. Feridex IV (ferumoxides injectable solution) [package insert]. Wayne, NJ: Bayer Healthcare Pharmaceuticals Inc; 2007. Available from: http:/ www.amagpharma.com/documents/products/pdfs/feridex_insert.pdf Accessed June 18, 2013.

17. Martwiset S, Koh AE, Chen W. Nonfouling characteristics of dextrancontaining surfaces. Langmuir. 2006;22(19):8192-8196.

18. Stankovich S, Dikin DA, Piner RD, et al. Synthesis of graphene-based nanosheets via chemical reduction of exfoliated graphite oxide. Carbon 2007;45(7):1558-1565.

19. Tang M, Dou H, Sun K. One-step synthesis of dextran-based stable nanoparticles assisted by self-assembly. Polymer. 2006;47(2):728-734

20. Zatz JL. Physical stability of suspensions. J Soc Cosmet Chem. 1985;36(6):393-411

21. Tweedle MF. The ProHance story: the making of a novel MRI contrast agent. Eur Radiol. 1997;7 Suppl 5:225-230.

22. Hummers WS Jr, Offeman RE. Preparation of graphitic oxide. J Am Chem Soc. 1958;80(6):1339.

23. Shan C, Yang H, Han D, Zhang Q, Ivaska A, Niu L. Water-soluble graphene covalently functionalized by biocompatible poly-L-lysine. Langmuir. 2009;25(20):12030-12033.

24. Liu Z, Robinson JT, Sun X, Dai H. PEGylated nanographene oxide for delivery of water-insoluble cancer drugs. JAm Chem Soc. 2008;130(33): 10876-10877.

25. Kim YK, Kim MH, Min DH. Biocompatible reduced graphene oxide prepared by using dextran as a multifunctional reducing agent. Chem Commun (Camb). 2011;47(11):3195-3197.

26. Deray G, Jacobs C. Are low osmolality contrast media less nephrotoxic? Nephrol Dial Transplant. 1996;11(6):930-931.

27. American Society of Health-System Pharmacists. Quick Guide to Contrast Media. Bethesda, MD: Contrast Media and Medication Management Standard Resource Center; 2010.

28. Pugh ND. Haemodynamic and rheological effects of contrast media: the role of viscosity and osmolality. Eur Radiol. 1996;6 Suppl 2: S13-S15.

29. Voeltz MD, Nelson MA, McDaniel MC, Manoukian SV. The important properties of contrast media: focus on viscosity. J Invasive Cardiol. 2007;19(3):1A-9A.

30. Lancelot E, Idée JM, Laclédère C, Santus R, Corot C. Effects of two dimeric iodinated contrast media on renal medullary blood perfusion and oxygenation in dogs. Invest Radiol. 2002;37(7):368-375.
31. Caravan P. Protein-targeted gadolinium-based magnetic resonance imaging (MRI) contrast agents: design and mechanism of action. Acc Chem Res. 2009;42(7):851-862.

32. van Liempd S, Morrison D, Sysmans L, Nelis P, Mortishire-Smith R. Development and validation of a higher-throughput equilibrium dialysis assay for plasma protein binding. J Lab Autom. 2011;16(1):56-67.

33. Rimkus G, Bremer-Streck S, Grüttner C, Kaiser WA, Hilger I. Can we accurately quantify nanoparticle associated proteins when constructing high-affinity MRI molecular imaging probes? Contrast Media Mol Imaging. 2011;6(3):119-125.

34. Watts DL. The nutritional relationships of manganese. J Orthomol Med. 1990;5(4):219-222.

35. Sullivan JF, Blotcky AJ, Jetton MM, Hahn HK, Burch RE. Serum levels of selenium, calcium, copper magnesium, manganese and zinc in various human diseases. J Nutr. 109(8):1432-1437.

36. Aschner M, Aschner JL. Manganese neurotoxicity: cellular effects and blood-brain barrier transport. Neurosci Biobehav Rev. 1991;15(3): 333-340.

37. Morcos SK, Thomsen HS, Webb JA; Contrast Media Safety Committee of the European Society of Urogenital Radiology (ESUR). Dialysis and contrast media. Eur Radiol. 2002;12(12):3026-3030.

38. Prince MR, Zhang H, Zou Z, Staron RB, Brill PW. Incidence of immediate gadolinium contrast media reactions. AJR Am J Roentgenol. 2011;196(2):W138-W143.

39. Dillman JR, Ellis JH, Cohan RH, Strouse PJ, Jan SC. Allergic-like breakthrough reactions to gadolinium contrast agents after corticosteroid and antihistamine premedication. AJR Am J Oroentgenol. 2008;190(1): 187-190.

40. Kuefner MA, Feurle J, Uder M, Bautz W, Schwelberger HG. Influence of magnetic resonance contrast media on the activity of histamine inactivating enzymes. Acad Radiol. 2009;16(3):358-362.

41. ProHance ${ }^{\mathbb{R}}$ (gadoteridol) injection, solution [product label]. Princeton, NJ: Bracco Diagnostics Inc; nd. Available from: http://dailymed.nlm. nih.gov/dailymed/lookup.cfm?setid=778aee03-07d4c-481a-be8aa75db0702f5a. Accessed June 18, 2013.

42. MultiHance - gadobenate dimeglumine injection, solution [highlights of prescribing information]. Princeton, NJ: Bracco Diagnostics Inc; nd. Available from: http://dailymed.nlm.nih.gov/dailymed/lookup. cfm?setid=e56fd303-309e0c-490b-8f31-64fc267b4df5. Accessed June 18, 2013.

43. Magnevist ${ }^{\circledR}$ (brand of gadopentetate dimeglumine) [package insert]. Wayne, NJ: Bayer HealthCare Pharmaceuticals Inc; 2011. Available from: http://labeling.bayerhealthcare.com/html/products/pi/ Magnevist_PI.pdf. Accessed June 18, 2013.

44. Teslascan data sheet [webpage on the Internet]. Portland: RxList Inc.; 2009. Available from: http://www.rxlist.com/teslascan-drug.htm. Accessed July 15, 2013.

45. Optimark [package insert]. Hazelwood, MO: Mallinckrodt; nd. Available from: http://www.mallinckrodt.com/webforms/threecolumn. aspx?id=497. Accessed June 18, 2013.

46. Omniscan ${ }^{\mathrm{TM}}$ (gadodiamide) injection [product label]. Princeton, NJ: GE Healthcare; 2011. http://dailymed.nlm.nih.gov/dailymed/lookup. cfm?setid=1e9a37e2-f28a-4373-bf0f-3e9b60f42d8a. Accessed July 15, 2013.

47. Kobayashi H, Brechbiel MW. Dendrimer-based macromolecular MRI contrast agents: characteristics and application. Mol Imaging. 2003;2(1):1-10.

48. Yang K, Hu L, Ma X, et al. Multimodal imaging guided photothermal therapy using functionalized graphene nanosheets anchored with magnetic nanoparticles. Adv Mater. 2012;24(14):1868-1872.

49. Sitharaman B, Wilson LJ. Gadonanotubes as new high-performance MRI contrast agents. Int J Nanomedicine. 2006;1(3):291-295. 


\section{Supplementary materials \\ Calculation of the dose}

If the concentration of the MRI CA solution is $1 \mathrm{mg} / \mathrm{mL}$, and it is required to be intravenously administered at a dose of $100 \mathrm{mg} / \mathrm{kg}$ in a $200 \mathrm{~g}$ rat, the CA injection volume (v) is calculated as follows:

$\mathrm{v}(\mathrm{mL}) \times 1 \mathrm{mg} / \mathrm{mL}=100 \mathrm{mg} / \mathrm{kg} \times 200 \mathrm{~g}$

$\mathrm{v}(\mathrm{mL}) \times 1 \mathrm{mg} / \mathrm{mL}=(100 \mathrm{mg} / 1,000 \mathrm{~g}) \times 200 \mathrm{~g}$

$\mathrm{v}(\mathrm{mL}) \times 1 \mathrm{mg} / \mathrm{mL}=20 \mathrm{mg}$

$\mathrm{v}(\mathrm{mL})=20 \mathrm{mg} / 1 \mathrm{mg} / \mathrm{mL}$

$\mathrm{v}(\mathrm{mL})=20 \mathrm{~mL}$.

The total circulating blood volume in a $200 \mathrm{~g}$ rat has been assumed to be $\sim 12.8 \mathrm{~mL}$. Therefore, the injected volume percent $(\%)(\mathrm{P})$ is calculated as:

$\mathrm{P} \%=(20 \mathrm{~mL} / 12.8 \mathrm{~mL}) \times 100 \%$

$\mathrm{P}(\%)=156.25 \%$.

Similarly, if the concentration of the MRI CA solution is $1 \mathrm{mg} / \mathrm{mL}$, and it is required to be intravenously administered at a dose of $1 \mathrm{mg} / \mathrm{kg}$ in a $200 \mathrm{~g}$ rat, the CA injection volume (v) is calculated as:

$\mathrm{v}(\mathrm{mL}) \times 1 \mathrm{mg} / \mathrm{mL}=1 \mathrm{mg} / \mathrm{kg} \times 200 \mathrm{~g}$

$\mathrm{v}(\mathrm{mL}) \times 1 \mathrm{mg} / \mathrm{mL}=(1 \mathrm{mg} / 1,000 \mathrm{~g}) \times 200 \mathrm{~g}$

$\mathrm{v}(\mathrm{mL}) \times 1 \mathrm{mg} / \mathrm{mL}=2 \mathrm{mg}$

$\mathrm{v}(\mathrm{mL})=2 \mathrm{mg} / 1 \mathrm{mg} / \mathrm{mL}$

$\mathrm{v}(\mathrm{mL})=2 \mathrm{~mL}$.

The injected volume percent $(\%)(\mathrm{P})$ can be calculated as: $12.8 \mathrm{~mL} \times \mathrm{P}(\%)=2 \mathrm{~mL} \times 100 \%$

$\mathrm{P}(\%)=(2 \mathrm{~mL} / 12.8 \mathrm{~mL}) \times 100 \%$

$\mathrm{P}(\%)=1.56 \%$.

In humans, the total circulating blood volume in a $70 \mathrm{~kg}$ adult human is $5 \mathrm{~L}$. Therefore, if the concentration of the MRI CA solution is $1 \mathrm{mg} / \mathrm{mL}$, and a $100 \mathrm{mg} / \mathrm{kg}$ dose has to be administered in a $70 \mathrm{~kg}$ human, the injection volume (v) of CA can be calculated as:

$\mathrm{v}(\mathrm{mL}) \times 1 \mathrm{mg} / \mathrm{mL}=100 \mathrm{mg} / \mathrm{kg} \times 70,000 \mathrm{~g}$

$\mathrm{v}(\mathrm{mL}) \times 1 \mathrm{mg} / \mathrm{mL}=(100 \mathrm{mg} / 1,000 \mathrm{~g}) \times 70,000 \mathrm{~g}$

$\mathrm{v}(\mathrm{mL}) \times 1 \mathrm{mg} / \mathrm{mL}=7,000 \mathrm{mg}$

$\mathrm{v}(\mathrm{mL})=7,000 \mathrm{mg} / 1 \mathrm{mg} / \mathrm{mL}$

$\mathrm{v}(\mathrm{mL})=7,000 \mathrm{~mL}$.

The injected volume percent $(\%)(\mathrm{P})$ can be calculated as: $5,000 \mathrm{~mL} \times \mathrm{P}(\%)=7,000 \mathrm{~mL} \times 100 \%$

$\mathrm{P}(\%)=(7,000 \mathrm{~mL} / 5,000 \mathrm{~mL}) \times 100 \%$

$\mathrm{P}(\%)=140 \%$.

Similarly, if the concentration of the MRI CA solution is $1 \mathrm{mg} / \mathrm{mL}$, and it is required to be intravenously administered at a dose of $1 \mathrm{mg} / \mathrm{kg}$ in a $70 \mathrm{~kg}$ human, the CA injection volume $(\mathrm{v})$ is calculated as:

$\mathrm{v}(\mathrm{mL}) \times 1 \mathrm{mg} / \mathrm{mL}=1 \mathrm{mg} / \mathrm{kg} \times 70,000 \mathrm{~g}$
$\mathrm{v}(\mathrm{mL}) \times 1 \mathrm{mg} / \mathrm{mL}=(1 \mathrm{mg} / 1,000 \mathrm{~g}) \times 70,000 \mathrm{~g}$

$\mathrm{v}(\mathrm{mL}) \times 1 \mathrm{mg} / \mathrm{mL}=7 \mathrm{mg}$

$\mathrm{v}(\mathrm{mL})=7 \mathrm{mg} / 1 \mathrm{mg} / \mathrm{mL}$

$\mathrm{v}(\mathrm{mL})=7 \mathrm{~mL}$.

The injected volume percent $(\%)(\mathrm{P})$ can be calculated as: $5,000 \mathrm{~mL} \times \mathrm{P}(\%)=7 \mathrm{~mL} \times 100 \%$

$\mathrm{P}(\%)=(7 \mathrm{~mL} / 5,000 \mathrm{~mL}) \times 100 \%$

$\mathrm{P}(\%)=1.4 \%$.

If the concentration of the MRI CA solution is $100 \mathrm{mg} / \mathrm{mL}$, and it is required to be intravenously administered at a dose of $500 \mathrm{mg} / \mathrm{kg}$ in a $200 \mathrm{~g}$ rat, the CA injection volume (v) is calculated as:

$\mathrm{v}(\mathrm{mL}) \times 100 \mathrm{mg} / \mathrm{mL}=500 \mathrm{mg} / \mathrm{kg} \times 200 \mathrm{~g}$

$\mathrm{v}(\mathrm{mL}) \times 100 \mathrm{mg} / \mathrm{mL}=(500 \mathrm{mg} / 1,000 \mathrm{~g}) \times 200 \mathrm{~g}$

$\mathrm{v}(\mathrm{mL}) \times 100 \mathrm{mg} / \mathrm{mL}=100 \mathrm{mg}$

$\mathrm{v}(\mathrm{mL})=100 \mathrm{mg} / 100 \mathrm{mg} / \mathrm{mL}$

$\mathrm{v}(\mathrm{mL})=1 \mathrm{~mL}$.

The total circulating blood volume in a $200 \mathrm{~g}$ rat has been assumed to be $\sim 12.8 \mathrm{~mL}$.

Thus, the injected volume percent $(\%)(\mathrm{P})$ can be calculated as follows:

$12.8 \mathrm{~mL} \times \mathrm{P}(\%)=1 \mathrm{~mL} \times 100 \%$

$\mathrm{P}(\%)=(1 \mathrm{~mL} / 12.8 \mathrm{~mL}) \times 100 \%$

$\mathrm{P}(\%)=7.8$.

\section{Calculation of the plasma concentration for relaxivity}

At a $0.1 \mathrm{mmol} / \mathrm{kg}$ clinical dose, the total amount of MRI CA that will be injected in a $200 \mathrm{~g}$ rat will be $0.1 \mathrm{mmol} / \mathrm{kg} \times$ $0.2 \mathrm{~kg}=0.02 \mathrm{mmol}$.

With a total circulating blood volume of $\sim 12.8 \mathrm{~mL}$, the plasma concentration of $\mathrm{Gd}^{3+} \mathrm{CA}$ can be calculated as: $0.02 \mathrm{mmol} / 12.8 \mathrm{~mL}=0.001562 \mathrm{mmol} / \mathrm{mL}=1,562 \mu \mathrm{M}$.

As determined by ICP-MS, the $\mathrm{Mn}^{2+}$ in GNP-Dex by weight is $0.064 \%$. Therefore, the weight $(\mathrm{z})(\mathrm{mg})$ of $\mathrm{Mn}^{2+}$ ions in $1 \mathrm{~mL}$ of $7.8 \mathrm{mg} / \mathrm{mL}$ solution of GNP-Dex can be calculated as:

$100 \mathrm{mg} \times \mathrm{z}(\mathrm{mg})=7.8 \mathrm{mg} \times 0.064 \mathrm{mg}$

$\mathrm{z}(\mathrm{mg})=(7.8 \mathrm{mg} / 100 \mathrm{mg}) \times 0.064 \mathrm{mg}$

$\mathrm{z}(\mathrm{mg})=0.005 \mathrm{mg}$.

Converting mass of $\mathrm{Mn}^{2+}$ into moles (molecular weight [MW] of $\left.\mathrm{Mn}^{2+} 54.93\right)$ :

$0.5 \mathrm{mg}=\left(0.005 \times 10^{-3} \mathrm{~g} / 54.93 \mathrm{~g} / \mathrm{mole}\right)=9.08 \times 10^{-8}$ moles.

Thus, $7.8 \mathrm{mg} / \mathrm{mL}$ GNP-Dex solution has $9.08 \times 10^{-8}$ moles $/ \mathrm{mL}$ or $90.80 \mu \mathrm{M}$ of $\mathrm{Mn}^{2+}$ ions. This value is 17 times lower than the plasma concentration of $\mathrm{Gd}^{3+}$ chelate-based CA $(1,562 \mu \mathrm{M})$ at clinical dose. 
Table SI Concentration of unbound protein measured by ultraviolet-visible (UV-Vis) spectrophotometry at equilibrium

\begin{tabular}{lll}
\hline $\begin{array}{l}\text { Concentration } \\
\text { of GNP-Dex } \\
(\mathrm{mg} / \mathrm{mL})\end{array}$ & $\begin{array}{l}\text { Concentration } \\
\text { of unbound } \\
\text { protein in protein } \\
\text { compartment } \\
(\mathrm{mg} / \mathrm{mL})\end{array}$ & $\begin{array}{l}\text { Concentration } \\
\text { of unbound protein } \\
\text { in GNP-Dex } \\
\text { compartment } \\
(\mathrm{mg} / \mathrm{mL})\end{array}$ \\
\hline 0.1 & 0.03 & 0.03 \\
1.0 & 0.55 & 0.07 \\
10.0 & 5.44 & 0.53 \\
\hline
\end{tabular}

Notes: In the equilibrium dialysis method, at equilibrium, if no protein is bound to the material of interest, the distribution of unbound (free) protein needed to be equal (ie, $0.025,0.250$, and $2.500 \mathrm{mg} / \mathrm{mL}$ of human serum albumin [HSA] in each compartment for $0.1,1.0$, and $10.0 \mathrm{mg} / \mathrm{mL}$ initial concentrations of HSA, respectively) at the end of equilibrium in both HSA and graphene nanoplatelets intercalated with manganese $\left(\mathrm{Mn}^{2+}\right)$ ions, functionalized with dextran (GNP-Dex) solution compartments. If the protein was binding to the GNP-Dex, the remaining unbound protein had to be distributed equally in both compartments. At equilibrium, $400 \mu \mathrm{L}$ solutions were retrieved (initial volume $500 \mu \mathrm{L}$ ) from both compartments and were used to measure unbound protein concentration. The concentration of unbound HSA at the end of 24 hours' incubation with the nanoparticles, as measured by UV-Vis spectrophotometry at $562 \mathrm{~nm}$, did not decrease, which implies that no protein was bound to GNP-Dex.

Table S2 Concentration of released $\mathrm{Mn}^{2+}$ ions in graphene nanoplatelets intercalated with manganese $\left(\mathrm{Mn}^{2+}\right)$ ions, functionalized with dextran (GNP-Dex) solutions at $37^{\circ} \mathrm{C}$ measured by ultraviolet-visible (UV-Vis) spectrophotometry to determine thermal stability

\begin{tabular}{ll}
\hline Sample & Mn $^{2+}$ concentration $(\mu \mathrm{M})$ \\
\hline GNP-Dex $20 \mathrm{mg} / \mathrm{mL}$ & $<$ LOD $(0.01)$ \\
GNP-Dex $50 \mathrm{mg} / \mathrm{mL}$ & $<$ LOD $(0.01)$ \\
GNP-Dex $100 \mathrm{mg} / \mathrm{mL}$ & $<$ LOD $(0.01)$ \\
\hline
\end{tabular}

Notes: There was no color change observed by sodium bismuthate $\left(\mathrm{NaBiO}_{3}\right)$ test in GNP-Dex solutions at 3 and 24 hours. The $\mathrm{Mn}^{2+}$ concentration measured by $\mathrm{UV}-\mathrm{Vis}$ spectrophotometry was less than limit of detection (LOD).
Table S3 Concentration of released histamine in whole human blood in vitro measured after overnight incubation with graphene nanoplatelets intercalated with manganese $\left(\mathrm{Mn}^{2+}\right)$ ions, functionalized with dextran (GNP-Dex)

\begin{tabular}{ll}
\hline $\begin{array}{l}\text { Concentration of GNP-Dex } \\
(\mathbf{m g} / \mathbf{m L})\end{array}$ & $\begin{array}{l}\text { Released histamine } \\
(\mathbf{n g} / \mathbf{m L})\end{array}$ \\
\hline Control & 19.8 \\
10.0 & 8.80 \\
1.0 & 5.59 \\
0.1 & 5.59
\end{tabular}

Note: The histamine concentration in GNP-Dex was found to be lower than in the control (not treated with GNP-Dex), which suggests that GNP-Dex do not trigger histamine release.
International Journal of Nanomedicine

\section{Publish your work in this journal}

The International Journal of Nanomedicine is an international, peerreviewed journal focusing on the application of nanotechnology in diagnostics, therapeutics, and drug delivery systems throughout the biomedical field. This journal is indexed on PubMed Central,

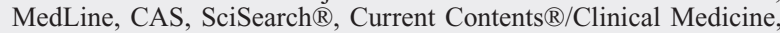

\section{Dovepress}

Journal Citation Reports/Science Edition, EMBase, Scopus and the Elsevier Bibliographic databases. The manuscript management system is completely online and includes a very quick and fair peer-review system, which is all easy to use. Visit http://www.dovepress.com/ testimonials.php to read real quotes from published authors.

\footnotetext{
Submit your manuscript here: http://www.dovepress.com/international-journal-of-nanomedicine-journal
} 